\title{
From Cowboys to Diplomats: Challenges for Social Entrepreneurship in The Netherlands
}

\author{
Marten J. Witkamp • Lambèr M. M. Royakkers • \\ Rob P. J. M. Raven
}

Published online: 29 June 2010

(C) The Author(s) 2010. This article is published with open access at Springerlink.com

\begin{abstract}
Social entrepreneurship - a new business model that combines a social goal with a business mentality - is in a transitional phase, from a rough cowboy market to a more established market niche. This process results in two interconnected dilemmas for the social entrepreneur. First, how it can capture market share despite its role as an antagonist to current market values. Second, how it can prevent the loss of its own core values in the course of greater interaction with the incumbent regimes. Using a tool known from innovation sciences to analyse radical innovations, namely strategic niche management, and both survey data and interviews from actors in the Netherlands, this article shows that social entrepreneurs have an attitude that is still more in line with the cowboy market than with the new diplomatic role they are expected to take on. Subsequently, it provides recommendations on how to achieve this new attitude.
\end{abstract}

Résumé L'entrepreneuriat social - un nouveau modèle économique qui combine un objectif social avec une mentalité d'entreprise - est dans une phase de transition, passant d'un marché d'amateurs difficile à un marché de niche bien établi. Ce phénomène donne lieu à deux difficultés interconnectées pour l'entrepreneur social. Tout d'abord, comment ce dernier peut gagner des parts de marché en dépit de son

\footnotetext{
M. J. Witkamp ( $₫)$

Dutch Research Institute for Transitions, Erasmus University Rotterdam, Rotterdam, The Netherlands

e-mail: work@martenwitkamp.nl

L. M. M. Royakkers - R. P. J. M. Raven

School of Innovation Sciences, Eindhoven University of Technology, Eindhoven,

The Netherlands

e-mail: 1.m.m.royakkers@tue.nl

R. P. J. M. Raven

e-mail: r.p.m.raven@tue.nl
} 
rôle d'antagoniste de la valeur marchande actuelle. Deuxièmement, comment il peut éviter la perte de ses valeurs fondamentales propres à l'occasion de relations plus étroites avec les régimes en place. En utilisant un outil connu des sciences de l'innovation pour analyser les innovations radicales, à savoir la gestion des créneaux stratégiques, les données d'études et les interviews de protagonistes aux Pays-Bas, cet article montre que les entrepreneurs sociaux ont une attitude qui est encore davantage conforme au marché d'amateurs qu'au nouveau rôle diplomatique qu'ils sont appelés à jouer. Il émet par la suite des recommandations sur la façon d'accéder à une nouvelle attitude.

Zusammenfassung Die soziale Unternehmerschaft - ein neues Unternehmensmodell, dass ein soziales Ziel mit einer Geschäftsmentalität vereint - befindet sich in einer Übergangsphase von einem primitiven Cowoboy-Markt zu einer etablierteren Marktnische. Dieser Prozess hat für den sozialen Unternehmer zwei ineinandergreifende Dilemma zur Folge. Erstens, wie kann er trotz seiner Antagonistenrolle gegenüber aktuellen Marktwerten einen Marktanteil gewinnen? Zweitens, wie kann er den Verlust seiner eigenen grundsätzlichen Werte im Zuge der vermehrten Interaktion mit den herrschenden Regimen vermeiden? Anhand eines Hilfsmittels, das in der Innovationswissenschaft zur Analyse radikaler Innovationen bekannt ist, nämlich dem strategischen Nischenmanagement, und mittels Erhebungsdaten und Befragungen von Akteuren in den Niederlanden zeigt dieser Beitrag, dass soziale Unternehmer noch immer eine Haltung einnehmen, die mehr dem Cowboy-Markt entspricht als der neuen diplomatischen Rolle, die sie übernehmen sollen. Anschließend werden Empfehlungen dazu abgegeben, wie diese neue Haltung erreicht werden kann.

Resumen El espíritu emprendedor (un nuevo modelo empresarial que combina los objetivos sociales con la mentalidad empresarial) constituye una fase de transición: de un mercado de duros cowboys a un nicho de mercado más consolidado. Este proceso provoca dos dilemas interrelacionados con el espíritu social. En primer lugar, cómo puede captar la cuota de mercado pese a su función como antagonista de los valores del mercado actual; y en segundo lugar, cómo puede evitar la pérdida de sus valores esenciales en el transcurso de una interacción mayor con los regímenes interesados. Utilizando una herramienta conocida por las ciencias de la innovación para analizar las innovaciones radicales, es decir, la gestión de nichos estratégicos y tanto datos como las entrevistas y las encuestas a actores en los Países Bajos, este trabajo revela que los emprendedores sociales siguen mostrando una actitud más en consonancia con el mercado de los cowboys que con el nuevo papel diplomático que se espera que asuma. Posteriormente, se ofrece una serie de recomendaciones sobre cómo lograr esta nueva actitud.

Keywords Business model - Social entrepreneurship · Social innovation · Regime $\cdot$ Strategic niche management $\cdot$ Systemic change 


\begin{abstract}
Abbreviations
CIC Community Interest Company

EMES L'Emergence des enterprises sociales en Europe (Emergency of Social Enterprise in Europe EU Research Programme)

RISE Research Initiative on Social Entrepreneurship

SNM Strategic niche management

SROI Social return on investment

SSO Stichting Sociaal Ondernemerschap (Society for Social Entrepreneurship)
\end{abstract}

\title{
Introduction
}

Social entrepreneurship (SE) has become something of a buzzword in academic and business circles of late. Many authors have stressed the potential for this unconventional combination of business tactics and social purpose in a single organisation to tackle the social problems of today (e.g. Nicholls 2006; Mair et al. 2006; Bornstein 2004). With all the scholarly attention for social entrepreneurs and their undertakings, however, there is still confusion over what is it although much has been accomplished on this front-and what its future prospects are. Most notably, research suggests that as an innovation grows mature and its protagonists start interacting with actors who have an interest in maintaining the status quo, core values from the innovation may become jeopardised (Smith 2007, p. 442). In civil society literature this phenomenon of shifting core values is called 'mission drift' (Weisbrod 2004; Jones 2007). This article's goal is to provide a theoretical basis for the further diffusion of (the core values of) social entrepreneurship, using the Netherlands as the geographical locus of analysis.

As Sud et al. (2008) have shown, social entrepreneurial activity is desirable and promising, even though we should not expect it to solve all the pressing social ills of this age. Murphy and Coombes (2008), on the other hand, have described how social entrepreneurs discover their distinct ways to create value. This article adds to this debate by applying an innovation sciences analysis-namely strategic niche management (SNM) - to a 57 case survey and eight interviews. It establishes how social entrepreneurs behave in practice and what their relation is to business and civil society regimes. ${ }^{1}$ Finally, we argue, in disagreement with an argument made by Sud et al. (2008) that a certain degree of institutional isomorphism in the sector is a necessary prerequisite for the diffusion of SE.

\section{Social Entrepreneurship as a Radical Innovation}

As innovation research has shown, there are two types of innovation: incremental and radical (Abernathy 1978, pp. 68-81). The latter type departs from previous designs and incorporates change in, for example cognitive frameworks and infrastructure, such as when electric light bulbs made artificial lighting much cleaner and more easily accessible than improvement in oil lamp designs would ever allow, but also required

\footnotetext{
${ }^{1}$ A comparison to a regime describing non-profit service providers would also be useful for the Dutch situation, considering that such organisations are widely operational in The Netherlands and have tried to claim the title 'social enterprise'. More research on this front could be valuable.
} 
the deployment of a wide network of electricity distribution. Such radical innovations are at the time of market introduction always immature relative to incumbent technologies (Schot and Geels 2008, p. 1), including amongst others a lack of an established network of actors and dominant rules of design. SE, as a new way of doing business and achieving social goals simultaneously, is such a potentially radical innovation. It combines two objectives hitherto considered mutually exclusive, i.e. making a profit and pursuing a social goal.

Theory suggests that as the actors that drive the radical innovation strive for a greater diffusion of their product or idea, there is a period of mutual adjustment between the innovation's values and those of the dominant regime, called translation (Smith, 2007, p. 443). Depending on the level of (in)compatibility between the innovation and the regime(s) it challenges core values of the innovation may become jeopardised in the search for a greater market, for example when successful ecofood brands were bought by large food producers who incorporated them into the global food chain, in opposition to the ecofood value of using local produce (Smith 2007). This raises the questions: which values are central to social entrepreneurship, which ones are in opposition to those of competing regimes, and what translation opportunities_values that niche and regimes share_can we identify?

\section{Usability of Strategic Niche Management}

The study of SE has been approached from various angles, such as case study descriptions (e.g. Bornstein 2004; Leadbeater 1997), practitioner guides (e.g. Boschee 2001; Dees et al. 2002) and especially business administration (e.g. Mair et al. 2006; Nicholls 2006). These studies often focus on the meaning of SE and how it can be told apart from other types of entrepreneurship or social purpose organisations. A topic of interest is the scaling up (of the impact) of social enterprises, since this seems to happen in ways that are different from normal enterprises (Dees et al. 2004; Alvord et al. 2004). So far, however, no one has addressed the question of how the movement of SE can itself be expected to grow and consolidate, or, in other words, researched the constraints that the systemic context within which social entrepreneurs have to operate imposes on growth of the sector. This is a particular strength of SNM through its regime concept (see below), which was an important rationale for choosing SNM as the conceptual framework. We have used this framework to research growth barriers and opportunities. SNM positions desirable, immature, radical innovations against established regimes that support an incumbent technology. The original question in SNM is 'how to understand and influence the early adoption of new technologies with high potential to contribute to sustainable development' (Schot and Geels 2008, p. 1).

$\mathrm{SE}$ is not a technological innovation in the classical sense of the word technology. A technology usually culminates in an artefact that does something. A technology is or contains a tangible object, many would argue. Even though the school of innovation sciences from which SNM originates uses a more sociological approach to technology (e.g. Geels 2004)—looking at, for example involved actors, laws, consumer expectations, etc.-it still centres around socio-technical artefacts. $\mathrm{SE}$ is neither so tangible nor can it be classified as an artefact. It is a new way of doing business, or a new way of pursuing social goals and in that sense, is certainly 
an innovation 'with promise for a more sustainable future'. In (self-identifying reference), the theoretical issue of whether and how SNM can be applied to analyse intangible innovations is further explored, since this had not yet been established. Suffice it to say here that, with a few adaptations to the tool also summarised in this text, SNM was found to be applicable to social innovations.

\section{Background}

Two fields form the backbone of this article, namely SE and SNM research.

\section{Social Entrepreneurship}

SE has attracted quite some interest in the past several years, although there is still confusion over what it really is and what different guises it takes on in different countries. An important text in this respect is the article by Peredo and McLean (2006). They analyse literature on both the entrepreneurial and the social aspect of the concept. Concerning the entrepreneurial half, Dees (1998) is credited with summing up three important characteristics of social entrepreneurial activity, namely (1) 'the recognition and (exploitation) of new opportunities to serve (the social) mission'; (2) 'engaging in a process of (...) innovation'; and (3) 'acting (...) without being limited by resources currently in hand', i.e. thinking big (Dees 1998, p. 4). In addition, as amongst others Tan et al. (2005) have noted, is the social entrepreneur's (4) 'capacity to endure risk'.

The crux, however, is the application of these entrepreneurial characteristics to a type of mission that is not focused on financial profit. Instead, as Peredo and McLean formulate, a social entrepreneur will use this entrepreneurial stance to (5) 'aim either exclusively or in some prominent way to create social value of some kind' (2006, p. 64).

There have been many debates over how prominent the social goal should be in relation to the financial one for an organisation to qualify as social-entrepreneurial. Peredo and McLean argue that it is impossible to draw a distinct line between enterprises whose social goal is subordinate to its financial one and those for whom it is not. Moreover, they find the distinction pointless, since 'the underlying point is surely that the pursuit of socially valuable outcomes is something worth identifying and fostering' (Peredo and McLean 2006, p. 63). In their view, social entrepreneurs can operate in a continuum from non-profits on one extreme to 'normal' firms that also have some sort of social goal, for whatever motivation, at the other extreme. In other words, corporations could thus be said to act in a social-entrepreneurial way if only they explicitly pursue some social goal besides their financial one (and comply with the other four above-mentioned characteristics).

This definition is supported by existing case study descriptions that observe that SE seems to occur across all sectors and in all different shapes and sizes, including on both sides of the previously divisive line between for-profit and not-for-profit (e.g. Bornstein 2004; Borzaga and Defourny 2001).

This five point definition, though, is rather inclusive. With some imagination it could point to (the next step for) all business and civil society organisations. This 
inclusiveness does not give a strong lead about whom to turn to in order to assess the state of SE in The Netherlands. The "Methodology" section will detail how this is established instead.

SE appears to take on alternative guises around the globe. Kerlin has made a comparison of US and European social enterprise and concluded that there are indeed notable differences (Kerlin 2006). In fact, even the phrase social enterprise can be used to describe two things: an organisation that was set up by a social entrepreneur, or an organisation with a social mission, such as housing corporations, hospitals and schools. The latter is less entrepreneurial in nature than the former, and is more frequently used in literature (e.g. De Waal 1994) since it predates the concept of SE. This article focuses on SE and not on social enterprise, because the novel solutions to social problems as described by, e.g. Bornstein (2004), Leadbeater (1997) and Mair et al. (2006), arise from social entrepreneurs and not from social enterprise. Since there is more literature on social enterprise than on SE, however, and since the two phenomena are related, this paragraph nevertheless paraphrases some relevant studies on the topic.

For social enterprise in the United States, there is no possibility for profit distribution for organisations that wish to institutionalise their social purpose, "while the European allows at least some mainly due to the inclusion of cooperatives in the definition' (Kerlin 2006, p. 249). Similarly, social enterprises in Europe are seen to be part of the social economy, whereas in the United States this concept does not exist and all organisations are seen to operate in the market economy (Kerlin 2006, p. 249). In the USA, Columbia Business School set up the Research Initiative on Social Entrepreneurship (RISE) in 2002, which published a 'snapshot of the landscape of US for-profit social ventures' in 2006 (Clark and Ucak 2006, p. 4). In Europe, EU research network EMES (L'Emergence des enterprises sociales en Europe) was instituted in 1996 to study the emergence of social enterprise, upon which it published a book in 2001 (Borzaga and Defourny 2001). In other parts of the world there are certainly social entrepreneurs, but research on them is scarce and such general conclusions as made by Kerlin or detailed descriptions as given by RISE or EMES have not yet become available for these countries.

Unfortunately, there is no reliable data on how many social entrepreneurs are active in the world, since they are not a separately tracked entity. An exception to this is the United Kingdom, where a number of legal entity types that are more conducive to SE have recently been created. The Community Interest Company (CIC) is the most well-known and relevant of these (CIC 2007), having attracted nearly 850 new companies between July 2005 and March 2007 (CIC 2007, p. 3) and counting 1935 companies as of July 2008.

The Netherlands usually holds middle ground between Anglo-Saxon and Germanic traditions (Hofstede 1980). It is therefore not evident in which of the two above-named directions SE is expected to be taking form in this country. There have so far been just a few inquiries into the state of SE in the Netherlands. ${ }^{2}$ Renooy

\footnotetext{
2 There have been more studies of individual organisations and the way that they work, create value, etc., e.g. by Maase and Dorst (2007).
} 
published a chapter in Borzaga and Defourny (2001, pp. 236-251) and Kievit is in the process of writing his doctorate thesis at Nyenrode Business University.

Renooy discusses the shape of social enterprise in the Netherlands and concludes that it was very much influenced by the so-called 'pillarisation' process. In this process that lasted through most of the twentieth century, each pillar (group of people with certain shared characteristics, e.g. catholics or liberals) gave rise to its own institutions. Examples of the kind of institutions that were formed are the media, labour unions and pension funds. There have therefore been many independent organisations with a social purpose for a long time. As a result, the employment in the social economy is very high, the highest in the world at $12 \%$ (Renooy 2001, p. 236). Nevertheless, the sector's dependency on government funding delimits the opportunities for more entrepreneurial social-purpose organisations.

Kievit investigates what the crucial variables are for the practice of social venturing in the Netherlands. Social venturing can be described as the investment activities that complement SE. While his thesis (Kievit 2011) is not yet available at the time of this writing, an interview with Kievit complemented by an article he published with Van Dijk and Spruyt in Holland Management Review (Kievit et al. 2008) paint the following picture: social venturing operates across the borders of the traditional tri-partition of society into government, firms, and civil society. It shares its problem perception with philanthropic organisations, but addresses these problems in a more entrepreneurial way, e.g. dependency is endemic for normal philanthropy, but something to be avoided at all costs for social ventures. Moreover, higher financial returns in time lead to a greater social impact (i.e. the multiplier effect), and is thus also considered a goal. Lending under favourable conditions, but not giving, is the adage. Kievit stresses the importance of the individual social entrepreneurs and ventures, their vision and their networks, for achieving efficient solutions. He therefore suggests that much of the success of social ventures is attributable to personal motivation and values.

\section{Strategic Niche Management}

SNM assumes that radical technological breakthroughs are necessary to attain a more sustainable society, and that these breakthroughs happen in a so-called sociotechnical context-meaning that stimulating innovation is not just a question of encouraging technological progress, but of a whole interplay between technological and societal factors. This article applies SNM to a social innovation and will thus use a variation of the tool adapted for the use with social innovations instead of technological ones. The adaptations in question are expounded upon in selfidentifying reference (2010). A summary of that narrative is given below.

A central concept in the field of SNM is that of the socio-technical regime. Geels introduced the phrase in 2004 (Geels 2004, p. 13), describing it as a number of interacting regimes in different domains, namely in the technological, scientific, political, socio-cultural, and user- and market-domain, centred around a particular technological system or artefact. A regime, in general, consists of the shared rules that govern a dominant design or dominant way of achieving things in the respective sector. The interplay between all of these five regimes is what finally determines the 
way that a given social function is fulfilled. The socio-technical regime is slightly adapted for use with a social innovation and is renamed to a value-based regime, as depicted in Fig. 1. First, the technological regime is replaced by the business model regime. The technological regime's role in the socio-technical regime is that of defining design, or how to make the artefact. Similarly, for SE, the question is how to design an organisation that can offer the (continued) provision of a service to society. The social entrepreneurs' ability to use both voluntary, public and market revenue in their business is one of their distinguishing innovations. Second, another issue deserves attention: the use of a technical artefact around which both niche and regime are defined in the original SNM approach. For a socio-technical regime, technology is the entry point of analysis, a tool to help in achieving focus. SE is not an artefact but a new way of doing business and solving a social problem driven by an emerging social group. This means that both niche and regime analyses in this case need an entry point other than an artefact. The entry point will have to take on a role similar to that which the artefact currently has, namely a starting point for analysis that inspires a certain natural understanding of what niche and regime are about. This article uses quotes for this role, although any representative social entity is in principle possible. The criteria used for this case study were that quotes should (a) be deemed by people to exemplify the respective regime and (b) represent the core values of the respective regime. It is possible that multiple quotes satisfy these criteria for any regime and that different researchers would each find a different quote for the same regime. We would argue that this is not a problem, as long as the criteria for finding the quote are explicit.

A radical innovation in its early phase always holds more promise than actual performance. If it would be immediately exposed to full market competition, it would not be likely to survive. A 'technological niche', as introduced by Schot et al. (1996), centres around such a potentially radical innovation and is the focal point of SNM. It prescribes temporary and partial protection from full market pressure, allowing the strengthening of the innovation by experimentation and learning. The goal of these experiments is the creation of new rules and heuristics that can guide the further development of the innovation and thus reduce the involved risk and increase its performance (i.e. helping the niche create the traits that make regimes so beneficial). The strength of the niche is described by an interplay of three niche characteristics (Elzen et al. 1996). First, articulating shared expectations by the

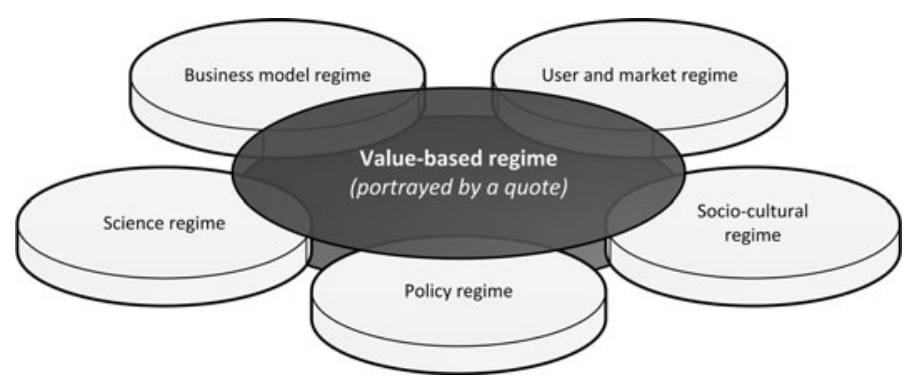

Fig. 1 Value-based regime 
participating actors give direction and legitimacy to the niche. Second, a growing social network including all relevant types of actors within the niche both creates opportunities for stakeholder interaction and a micro market that provides the resources necessary for experimentation and temporary protection. Third and most importantly, a learning mechanism (between experiments, between actors, etc.) is a vital ingredient for the establishment of new rules and design heuristics. The better developed these three dimensions are, the greater the chance that the niche can develop into a market niche or become a viable alternative to an existing regime.

\section{Scaling Up}

Internal processes of articulating expectations, learning and networking are critical in the initial shaping and construction of niches. In the process of scaling up niches, however, interactions with prevailing regimes become more important. To achieve some detail concerning the level of compatibility between niche and regime, this research focuses on conflicting and shared values. Values are an essential part of the development of a niche and a source of expectations, rules, routines and design heuristics. Smith (2007) describes that, in the process of translation from niche to a market niche or regime, values may be sacrificed. This leads to a translation paradox: while a larger market share for the niche can be desirable from a societal point of view, at what point does a further sacrifice of values transform it from a radical to an incremental innovation (with much lower benefits)? This paradox relates to the isomorphism argument postulated by Sud et al. (2008) on the question of social entrepreneurs' power to solve social problems, which states that new types of institutions such as SE are pressured into resembling each other and the other already existing types of institutions and that this is deplorable since it corrupts the innovative capacity of the new institutions. While these authors reject every form of isomorphism, we reply that it is impossible to prevent since it is directly related to the human wish to simplify nature. Without a certain degree of isomorphism, the new institution will remain promising but never understood and thus marginal. We propose that it is important for the SE niche to formulate its core values, so it can resist isomorphic pressures that require a compromise of these values and thus corrupt its innovative capacities, but that it simultaneously actively seeks isomorphism regarding all other aspects of its institution. The "Analysis and Conclusions" section provides a starting point for the formulation of these core values. Jones (2007), in studying nonprofits, established that organisations with a 'social' mission tend to experience 'mission drift', slowly leading activities away from the social mission and more in line with political or market pressures. At that point, however, safeguarding against mission drift is related to strategic management within an organisation, whereas the isomorphism argument relates to the niche as a whole.

\section{Methodology}

The SNM tool is made operational in this section. The analysis consists of two parts: first, there is the issue of how well developed the niche is, i.e. a study of the internal 
niche dynamics of SE in the Netherlands. Second, the interaction between niche and regime(s) is characterised. In addition, the sources for this analysis are discussed in the last paragraph of this section.

\section{Internal Niche Dynamics}

Even though the section on SE has established that there is no theoretically meaningful line between companies that let social prevail above financial purposeor vice versa - an analytical distinction must nevertheless be made to discern between those organisations that this study focuses on and those it does not. Since the major goal of this article is to assess the growth potential of social entrepreneurs, it makes sense to focus on those entrepreneurs that are the most explicit exponents of this group, i.e. in their pursuit of both financial and social return, since they are likely to clash with existing regimes the soonest and most frequently.

The Dutch Society for Social Entrepreneurship (SSO, after its Dutch initials) is a private non-profit network building organisation that aims to diffuse the practice of SE in the Netherlands. It has a network of about 200 social entrepreneurs, which it estimates to comprise a representative one-fifth of all social-entrepreneurial activities in the country. ${ }^{3}$ The activities of the companies in their network are the subject of the niche that is described here.

The three previously briefly named dimensions-social network, expectations and learning processes - can be expanded into measurables as follows (Elzen et al. 1996, pp. 76-78). First, the social network has both width and depth. The width alludes to the type and number of actors present in the network, bearing in mind the five types of regimes interacting in the value-based regime (see Fig. 1): business model, science, policy, socio-cultural, and user and market. The depth is a measure for how involved actors are. If a network is built up of, say, a number of juniors from several organisations, that network is less powerful than if it were consisting of the Chief Executive Officers of those same organisations.

Second, expectations consist of three variables: robustness, detail and quality. Robustness gives an impression of how widely shared, in this case, the definition and role of SE is. The level of detail about which there is consensus regarding the definition and role of SE adds to understanding the strength of these expectations. The quality of the expectations depends on whether they are based on facts and reality rather than on wishful thinking, i.e. how tangible they are.

Finally, learning mechanisms can be of either first or second order. In this scenario, first order mechanisms would refer to ways to acquire and disseminate knowledge about, for example success factors for social entrepreneurs or the dangers and benefits of specific social-business models. They 'facilitate alignments between variation and selection and create "configurations that work" (Schot and Geels 2008, p. 5). Second order learning, on the other hand, is what takes place when the philosophy of the niche, in this case that making a profit and solving social

\footnotetext{
3 Estimates vary strongly from one actor to the other, depending on their definition of what social entrepreneurship is, and range from a couple dozen to a thousand. The definition of SSO is in line with the theoretical description set out for this research, and is thus rather inclusive. Nevertheless, it still only includes organisations explicitly combining financial and social goals.
} 
problems can go hand in hand, starts to permeate the dominant regime(s). There is an additional analytic distinction between broad and narrow learning-where broad refers to more general contextual knowledge and narrow to more specific nittygritty knowledge - that is not used here because the specific knowledge of how to operate a social entrepreneurial business model is inherently contextual and thus also general. In other words, SE is holistic.

\section{Niche-Regime Interaction}

The definition of the regime against which SE is pitched as a niche is a delicate step. In fact, two regimes are suggested versus just one, since the hybrid nature of SE leads it to be involved in conflict and cooperation with two regimes on either side of the spectrum. On the one hand, there is conventional business that has a per definition goal to maximise its profits notwithstanding, as long as it obeys the law. Social issues may be tackled by partisans of this regime, but only so much as it increases shareholder value, as Reich finely portrays (Reich 2007, p. 204). On the other hand, as Bornstein defines (2004, p. 4), lies the civil society regime that is concerned with social objectives, and for whom profit making is not a goal, but rather an impediment to their legitimacy. The table in Fig. 2 shows several important characteristics of these two regimes.

These regimes pose certain dilemmas to the development of SE (on which will be elaborated in the results) and their existence has been confirmed by interviews in the field. The last line in the table in Fig. 2 names an opportunity for innovation in both regimes. This is to indicate that these regimes are not static and that pressures on

\begin{tabular}{|c|c|c|}
\hline & BusINESS REgIME & CIVIL Society Regime \\
\hline Quote & $\begin{array}{l}\text { "The social responsibility of } \\
\text { business is to increase its profits." } \\
\text { - Friedman, } 1970\end{array}$ & $\begin{array}{l}\text { "I resolved to stop accumulating } \\
\text { and begin the infinitely more } \\
\text { serious and difficult task of wise } \\
\text { distribution." } \\
\text { - Carnegie, } 1920\end{array}$ \\
\hline $\begin{array}{l}\text { Rules } \\
\text { (or guiding principles or } \\
\text { heuristics, as varying } \\
\text { authors may call them) }\end{array}$ & $\begin{array}{l}\text { - The financial bottom-line is the } \\
\text { indicator of success. } \\
\text { - Pursuing social goals compromises } \\
\text { business credibility. } \\
\text { - You sell products and services. }\end{array}$ & $\begin{array}{l}\text { - Member base is an important } \\
\text { indicator of success, but no } \\
\text { consensus exists on measures of } \\
\text { success. } \\
\text { - Pursuing financial goals } \\
\text { compromises legitimacy. } \\
\text { - You sell values. } \\
\text { - Large financial dependency on } \\
\text { government. }\end{array}$ \\
\hline Assumptions & $\begin{array}{l}\text { There are no or only minor market } \\
\text { and government failures. }\end{array}$ & $\begin{array}{l}\text { There are large market and } \\
\text { government failures. }\end{array}$ \\
\hline Important actors & $\begin{array}{l}\text { - Shareholders } \\
\text { - People as consumers } \\
\text { - Banks and investors } \\
\text { - Government insofar as it sets the } \\
\text { rules by which firms must play }\end{array}$ & $\begin{array}{l}\text { - Non-profit organisations (NPOs) } \\
\text { - People as citizens } \\
\text { - Government as partner and } \\
\text { financer }\end{array}$ \\
\hline Common legal entities & $\begin{array}{l}\text { Ltd., PLC, General Partnership, } \\
\text { Partnership, Sole Proprietorship, } \\
\text { Cooperative }\end{array}$ & $\begin{array}{l}\text { Foundation, Association, Sole } \\
\text { Proprietorship, Partnership, } \\
\text { Cooperative }\end{array}$ \\
\hline $\begin{array}{l}\text { Opportunities for } \\
\text { innovation }\end{array}$ & $\begin{array}{l}\text { Corporate Social Responsibility } \\
\text { (CSR), Cradle } 2 \text { Cradle (C2C) }\end{array}$ & Entrepreneurial NPOs \\
\hline
\end{tabular}

Fig. 2 The two regimes defined (Carnegie and Van Dyke 1920; Friedman 1970) 
them can also result in dynamism from within the regime itself. Those innovations, however, are likely not to change the rules of the game.

Values have been used to describe many different things, in many different contexts, but they always refer to underlying motivations or beliefs that do not change overnight, and that fuel more practical rules or behaviour. In focusing on the values that separate the SE niche from the two incumbent regimes, this research searches for fundamental differences between these three domains. These differences will not be absolved within a short time frame and must be acknowledged if the interaction between the niche and regimes is to be understood and improved.

When pitching niche against regime, one can identify values that are either conflicting or shared. Conflicting values will be betrayed by the barriers that the niche actors encounter. Shared values, on the other hand, can be extracted from stories of cooperation and mutual interest between actors from both domains.

\section{Sources}

This article has, apart from literature, two main sources. First is a reconnaissance of the field of SE in terms of participating in related events and interviews with actors from that field. Second is a data set that was created with a survey by SSO in conjunction with two social entrepreneurs, The Hub and Realize! and which has not been analysed in previous academic publications.

The people interviewed are actors in the field of SE and more often than not have a networking component to their activities. They are 'overviewers' rather than grassroots-level players. With the exception of actors from the regulatory fieldwhere there was no involvement worth mentioning-eight participants from the four other actor groups surrounding the value-based regime have been interviewed, i.e. from the business model, science, socio-cultural, and user and market regimes. ${ }^{4}$ Many of the interviewed actors play multiple roles in the niche, which is perhaps not surprising considering the early state of development it is in. The interviews can be characterised as semi-structured, with a number of questions based on the abovedescribed theory forming the starting point of the discussions. ${ }^{5}$

In addition, a survey was carried out to better understand the needs of social entrepreneurs in the Netherlands, and thus adds information from the perspectives of business model and user and market regimes. To obtain the survey sample, all visitors of the SSO website and members of their network were informed of its existence and asked to respond if applicable. De facto, this means that the respondents see themselves as social entrepreneurs or operating in this field. There were 73 respondents overall, of which 16 were deemed unusable because they did not answer enough questions, resulting in a sample of 57.

\footnotetext{
${ }^{4}$ The eight being: The Hub, Enviu, d.o.b. foundation, Kaospilots, SSO, VSB Fonds, Eindhoven University of Technology, and Nyenrode Business University.

5 The interviews for all actors except those from the science regime (which were conducted in an early phase of the research and were used more for orientation) have been written out in summary and can be requested with a note to the author.
} 


\section{Results}

The case study analysis presents us with the following view of the field of SE in the Netherlands. Each paragraph concerning the niche dynamics begins with presenting the relevant survey results, continues by describing the interpretation of these data based on the interviews and concludes with a synthesis on these facts in terms suitable for theoretical reflection. The paragraphs about the niche-regime interaction follow a similar pattern, but are less able to draw on survey data for a lack of appropriate questions in the survey.

\section{Internal Niche Dynamics}

Concerning the social network, the survey amongst social entrepreneurs shows that the average age of their organisation is 4.7 years, and the median age 2 years. The organisation consists of on average 1.6 founders (median =1), 2.8 partners (median $=1)$, and 5.4 employees (median $=1$ ). Of this sample group of social entrepreneurs, $53 \%$ is female, contrasting with figures for all types of entrepreneurship in the Netherlands, with a constant 30\% female throughout the years 19992004 (Centraal Bureau voor Statistiek 2008). Almost all, 89\%, of the respondents reside and work in the 'Randstad' - the heavily urbanised area from Utrecht via Amsterdam and The Hague to Rotterdam.

When asked to name important partners, the organisations most frequently named were the Chamber of Commerce (six times), Syntens (four times), Kunstenaars \& Co, SSO, The Hub and UWV (all three times). The first two of these explicitly focus on entrepreneurship, Kunstenaars \& Co aims to help artists become financially independent, UWV is a government agency tasked with stimulating employment, and finally SSO and The Hub are two actors that were previously mentioned and are dedicated to supporting social entrepreneurs.

The interviews add a storyline to these facts. It is acknowledged by all that SE has started to take off in the last 5 years. Important network-builders SSO and The Hub were initiated roughly simultaneously at the time, although there were already a number of previous Hubs in other countries (and still are). While there had been individual social entrepreneurs before then, they were not connected and not acknowledged as such. Even now, many social entrepreneurs do not call themselves by this name.

Two actors that did not come forward from the survey but were frequently mentioned in the interviews are private investors and university researchers. First, a number of private investors play a role in the encouragement of SE. These wealthy ex-entrepreneurs understand the power of business models, and now want to apply these to solving social problems. They are an important source of the venture capital on which social entrepreneurs depend. Second, the role of universities is small but growing. The Free University of Amsterdam, the private Nyenrode Business University, and to a lesser extent Erasmus University of Rotterdam are starting to pick up interest in the niche. This interest has so far not been translated into publications or official partnerships. 
From the point of view of the width of the network, this has evidently been growing considerably over the last few years, albeit from a very low base. The contact between and amongst entrepreneurs is the most strongly established of all links, with partners like SSO and The Hub facilitating the interaction. This network is reaching out to investors in an effort to involve them in the process of setting up new ventures. Institutional investors, however, still view this market as very risky and are awaiting more proof of performance. The academic institutions mentioned above are becoming more interested and approach the SSO/The Hub-network (not vice versa) for information. Government bodies and business regime organisations are, if at all, involved as clients.

The depth indicator on the other hand, shows that social entrepreneurial organisations are strongly involved in the social network. SE is either the only way they work or the only reason they exist. At the moment, though, these small organisations are also building relations with increasing numbers of incumbent firms, government agencies and cultural sector organisations, most of whom are bigger and more hierarchical. The survey enabled the respondents to give names of people important to their organisation, and quite a number of those named people were well-known public figures in the Netherlands. It appears as if some highly placed people at various positions throughout the business, political and academic landscape have become interested in this new way of doing business and solving social problems. Whether these people also call it SE is unknown but not expected. On the other side, connections with institutional investors and semi-public organisations such as the Chamber of Commerce and Syntens appear to be, although important, with people not particularly high in the hierarchy. Social entrepreneurs report frequently 'hitting a wall' with these (type of) organisations.

Regarding the field's expectations, the survey shows that, within the sample of 57 , there is a wide range of products and services on offer, sources of financial support, and legal entities under which the organisations operate. To illustrate the diversity: if one splits up the sample into three categories-according to three open questions: a description of the organisation, the organisation's mission, and the cause for initiating the organisation-the three categories being those most resembling business, those most resembling civil society, and those appearing to be most like textbook social entrepreneurs, there is a statistically significant difference between the answers they give to many of the questions, even within this sample of just 57 cases. $^{6}$ Nevertheless, there are also a number of shared characteristics, for example relating to the motivation and bottom-line of the organisation. First, the respondents were consistently double bottom-lined, both socially and financially, but not environmentally. Second, they are motivated especially by the social perspectives of their work. The difference between motivation and bottom-line can be seen as analogous to the difference between goal and means. The motivation is what leads to the organisation's start-up and its mission. The bottom-lines, if correctly transformed into a business model, lead to the organisation's continued

\footnotetext{
${ }^{6}$ For example, those most resembling business were less likely to use government subsidies than those appearing to be social entrepreneurs, and those looking like civil society were more likely to attach a high value to their financial bottom-line than the sample did as a whole.
} 
Fig. 3 Motivations and bottomlines of the respondents

\begin{tabular}{|c|c|c|}
\hline & MOTIVATION & BOTTOM-LINE \\
\hline People * & 4.4 & 3.8 \\
\hline Planet & 3.3 & 3.0 \\
\hline Profit* & 3.3 & 3.6 \\
\hline
\end{tabular}

existence. Figure 3 summarises these findings. The two starred rows indicate that the above-described findings are statistically significant.

Two other surveyed descriptors of the niche's expectations are its sources of financial capital and its legal forms of operation. Social entrepreneurs, as portrayed by the sample, use mixed sources of income simultaneously. On average, they use 1.5 different sources and plan to use another 1.5 additional sources in the near future. The most frequently used sources are shown in Fig. $4 .^{7}$ Notable is, amongst others, that very few make use of sources indispensable for conventional entrepreneurs, namely formal investors and bank loans and credits. This suggests that investors and banks see social entrepreneurs as an unproven business category and thus as a risk. A second observation is the very high importance of on the one hand the use of private financial reserves - a very strong indication of the immaturity of the niche and the existence of protection from market pressureswhile on the other hand funds, gifts and subsidies-primary sources for civil society - are also highly valued, and will become even more so, as indicated by the percentage planning to use this source in the near future. This is not just a result of averaging the responses, but also holds for individual cases. The use of mixed resources point to sectoral boundary-crossing activity. For social entrepreneurs, it is more important to reach their goal than to know to which sector they belong.

A final description based on the survey, the legal entities as which social entrepreneurs in the Netherlands operate, shows the following picture. ${ }^{8}$ About $46 \%$ are Sole Proprietorship, 28\% are a Foundation and $21 \%$ are a Private Limited Company (Ltd.). The other $14 \%$ consist of either a Partnership or a General Partnership. ${ }^{9}$ The diversity of legal entities demonstrates the differences in expectations that the various actors of the niche have. For example, the often used

\footnotetext{
${ }^{7}$ The columns can be added together because they are exclusive categories. Together with two other categories, namely 'have used, but not anymore' and 'not using and not planning to', the total always sums up to $100 \%$.

${ }^{8}$ The comparable Dutch legal entities are named Eenmanszaak (Sole Proprietorship), Maatschap (Partnership), Vennootschap onder Firma (General Partnership), Besloten Vennootschap (Ltd.), Naamloze Vennootschap (Public Limited Company), Stichting (Foundation), and Coöperatie (Cooperative).

${ }^{9}$ Note that this adds up to more than $100 \%$ since some organisations have multiple legal entities. Notably absent are the Public Limited Company, and the Cooperative. This last absentee is a central subject in the writings of Borzaga and Defourny (2001), but its absence can be explained by the difference between social enterprise, on which Borzaga and Defourny focus, and social entrepreneurship (see the theory section for a small discussion on this topic).
} 


\begin{tabular}{l|cc|c}
\hline SOURCE: & $\begin{array}{c}\text { Percentage using } \\
\text { this source: }\end{array}$ & $\begin{array}{c}\text { Percentage planning } \\
\text { to use this source: }\end{array}$ & Total: \\
\hline Own money & $53 \%$ & $11 \%$ & $64 \%$ \\
\hline Government subsidies & $26 \%$ & $26 \%$ & $52 \%$ \\
\hline Funds and gifts & $19 \%$ & $35 \%$ & $54 \%$ \\
\hline Contest prizes & $11 \%$ & $16 \%$ & $27 \%$ \\
\hline Formal investors & $2 \%$ & $28 \%$ & $30 \%$ \\
\hline Bank loans \& credits & $11 \%$ & $19 \%$ & $30 \%$ \\
\hline Informal sources & $11 \%$ & $11 \%$ & $22 \%$ \\
\hline Other sources & $16 \%$ & $9 \%$ & $25 \%$ \\
\hline
\end{tabular}

Fig. 4 Sources of financial capital

Foundation is known for its non-profit character and is not seen as innovative, while an Ltd. advocating social values will be regarded with much suspicion. Perhaps though, the expectations of social entrepreneurs are in reality largely similar, but there is no adequate legal entity to express it with. Either way, the expectations of social entrepreneurs as expressed by the legal entities they operate under are diffuse.

According to the interviews, double bottom-line entrepreneurship is indeed a central value of the niche, although some would rather see a triple (i.e. the 3 P's) than a double bottom-line and another adds that in practice it is more about the high intensity of the motivation and the orientation towards creating value than the focus on a bottom-line at all, meaning that social entrepreneurs are not consciously aware of making bottom-line choices but merely pursue their social goal in a new way. The importance of the 'desire to do things differently' returns frequently in the interviews, as well as in the given social missions of the 57 survey respondents, and appears to reflect the holistic nature of the change social entrepreneurs try to accomplish. Instead of pursuing solutions to part of the problem, social entrepreneurs try to envisage the entire problem and come up with systemic solutions. A recurring problem that they have to deal with, in this respect, is the need for appropriate value measurements, namely concerning social performance. Social entrepreneurs are actively engaged in finding, developing or adjusting such appropriate measures.

The niche actors formed these expectations partly on the basis of international experience and literature such as Bornstein (2004), and partly on the basis of people's own experiences in the business and civil society regimes. While formed in this way, they are adjusted on the basis of the activities that social entrepreneurs in the network surrounding the interviewed actors actually display.

Synthesising, shared expectations include a double bottom-line approach (both profit and people), a very high people-motivation, and the tendency to search for solutions to the source of the problem, not just to its visible consequences. Social entrepreneurs use mixed resources, especially their own and those coming from government, gifts and funds, and operate mostly under three legal forms, namely sole proprietorship, private limited company and foundation. Finally, they seek 
ways to display the social value that they are creating, both for their own performance indication and for the attraction of new clients. The robustness of these expectations is high, but there is as yet only very little known about social entrepreneurs as compared to other entrepreneurs or even organisations in civil society, and the detail is thus low. The last of the three variables describing expectations, the quality, is low. As the interviewed actors have acknowledged, SE must still prove itself. While the expectations of individuals in the niche may be built on experience with international developments and perhaps Dutch social entrepreneurs as well, the niche as a whole has no such basis of experiments to build on yet-in the Netherlands, that is. A number of cases is repeatedly cited as example, but these cases are few and have not yet been academically analysed. This does not mean that the expectations are wrong or too optimistic or pessimistic, but merely that the factual basis on which they are built is rather narrow.

The final niche dimension regards its learning processes. One of the questions the survey asks is which supportive measures social entrepreneurs would like there to be. Their answers emphasise a shortage in collective learning mechanisms, for example workshops, seminars, conferences, etc. At least three of the four top needs, of a total number of 16 measured support possibilities, can be attributed to the desire for collective learning and knowledge on how to practice SE. Of the four lowest rated needs, none involves collective learning and two can be said to include some personal learning, for example specialised training. The other eight needs do not differ significantly from the mean. Evidently, social entrepreneurs have difficulties meeting experts and pioneers in their field, would like more specialised workshops and seminars, and need to share experiences with successful entrepreneurs from other sectors. This suggests that, as of yet, there are insufficient possibilities for collective learning in this niche. These results are shown in Fig. 5.

The interviews show that much of the effort of intermediary organisations such as The Hub, Enviu and SSO is indeed devoted to getting social entrepreneurs in

\begin{tabular}{l|c} 
SUPPORTIVE NEEDS: & Response: \\
\hline Contact with potential partners or clients & 4.2 \\
\hline Contact with experts and pioneers in the field & 3.8 \\
\hline Workshops and seminars in the field & 3.6 \\
\hline Network of successful entrepreneurs from other sectors & 3.5 \\
\hline (middle 8 not significantly differing from average) & $\ldots$ \\
\hline Personal coaching & 2.8 \\
\hline Mentoring with respect to content & 2.7 \\
\hline Sharing costs (e.g. joint purchasing, shared service centre) & 2.5 \\
\hline Political representation & 2.5 \\
\hline
\end{tabular}

Fig. 5 Reported barriers to social entrepreneurship 
contact with each other and others, such as investors and experts. The experience of 'veteran' social entrepreneurs is diffused by workshops and project evaluations, open innovations takes place in communal office space, and free newsletters bundle the latest activities and research results.

So far, this concerns learning routed towards social entrepreneurs. Looking the other way, at the way that society learns from the experience of social entrepreneurs and perhaps incorporates common practice in this niche into its regimes, the interviewed actors all stress that now is the time for proving themselves and thereby gaining trust. Explaining the added value of social entrepreneurs remains difficult in a language accustomed to either making money or pursuing social value. Consequently, they view networking and convincing others by both talking and successfully executing projects as their primary ways of influencing the regimes, although a thorough academic study 'showing that social entrepreneurship works' would also be very welcome. They expect the coming few years to be critical in this respect, considering that there is now a momentum of interest in SE.

Summarising the findings concerning learning mechanisms, there is evidently a shortage of ways to engage in collective first order learning, as shown by the survey respondents' desire for more of these ways. The size and density of the network of social entrepreneurs are both relatively high for such a young niche. Also, there are multiple actors that provide learning services as requested by the respondents, such as workshops and contact with experts in the field. Nevertheless, there is a perceived shortage. Perhaps an alternative explanation for this lack of learning mechanisms is that there is an inadequate retention of knowledge gained by experience into a global knowledge base to draw upon, i.e. every new social entrepreneur has to start at the beginning since those who started before were not able to add their experience to the collective, or global, knowledge of the niche. This view is supported by many of the interviewed actors. The real deficiency in first order learning mechanisms, therefore, is one of the traits that also makes SE so powerful, namely the will to create new connections between people and organisations and new paths to social and financial value, no matter what the opposition. Cho referred to this attitude as monological (Cho 2006, p. 36); here it will be described by the word 'cowboy', analogous to the cowboy's determination to create its own path to value in unexplored or difficult terrain. This determination leads to a certain conservative attitude of the niche actors towards any definition of their activities that is perceived as limiting, while a partial limitation could greatly facilitate learning and thus increase the strength of the niche.

Second order learning mechanisms are different. Social entrepreneurs are very motivated by their enterprise and spread their enthusiasm to those they work with. This has led to increasing recognition of social entrepreneurs as experts in the field of multiple value creation and social innovation, as some of the interviewed actors relate. So far, their enthusiasm affects mostly individuals and has not been able to permeate into large bureaucracies such as the central government and large corporations, although there have been a few of the latter that are involved with social entrepreneurs. The mechanisms for this type of learning are foremost the projects carried out by social entrepreneurs and furthermore their networking capabilities. Finally, some actors have expressly dedicated themselves to educating 
and supporting young social entrepreneurs as a way to change the future landscape of entrepreneurship.

\section{Niche-Regime Interaction}

A conflicting value, as identified with the help of barriers experienced by niche actors, displays a fundamental conflict of rules between the niche and the respective regime. A shared value, as identified with the help of existing cooperation between actors from the niche and regime, represents a growth opportunity for SE that is most likely to avoid barriers as much as possible.

The survey shows that social entrepreneurs have difficulties obtaining funds from sources indispensable for conventional business, namely bank loans and investors. This suggests that social entrepreneurs are not able to convince institutional actors that they are a good investment. The interviews support this view and add that this is in part due to the fact that investors do not know what to expect of the financial performance of social entrepreneurs, and in part because the social value created by these entrepreneurs cannot be capitalised upon by the investors and thus yield no added incentive to invest. This latter cause is a conflicting value between the niche of SE and the regime of business. Social performance is not one of the criteria by which most investors are judged, ${ }^{10}$ and thus they do not feel pressure to compete in this area. The issue of social performance measurement-for which multiple partial solutions exist, none of which is accepted as the standard-complicates this conflict of values.

Conflicting value 1: Institutional investors are not judged by social performance. (between social entrepreneurship niche and business regime)

Related to this is that cultural attitudes are adjusted to organisations pursuing just one goal at a time. While individuals are comfortable in balancing many different goals, e.g. making do with this week's budget, finding some leisure time and simultaneously completing a difficult task at work, organisations are expected to be one-issue actors. Evidence for this attitude comes from the inability of many institutional organisations like the Chamber of Commerce, government agencies, laws and subsidy programmes, and the aforementioned investors to put a tab on the dual purpose social entrepreneur. The interviews consistently stress that individual employees understand what SE is and that it can profitably combine two goals, but that these employees are not able to turn this understanding into appropriate supportive action because the rules that govern their respective organisations are incompatible with organisations that combine multiple goals. There does not seem to be an underlying logic to this lack of compatibility other than the robustness of the system.

\footnotetext{
${ }^{10}$ Sustainable investment funds are growing more rapidly than the market as a whole, leading to an increasing availability of investors interested in social performance. The limited socially interested funds, however, so far have invested their money abroad or in stocks, both of which exclude social entrepreneurs (recount the legal entities under which social entrepreneurs operate).
} 
Conflicting value 2: Governing systems are designed with single-purpose organisations in mind. (between social entrepreneurship niche and both business and civil society regimes)

The interviewed social entrepreneurs and related organisations confessed that it was still very difficult to explain to people outside the niche what SE is, how it functions and why it is important. What plays a role in this case is on the one hand the value displayed above, namely that multi-purpose organisations are not embedded in most people's and organisations' frame of mind. On the other hand, however, lies the earlier mentioned seeming inability of the SE niche to agree on how to call itself and how to express its core values. Organisations with barely noticeable differences in approaching social, financial and sometimes environmental value can be found to use such terms as SE, issue-driven entrepreneurship, sustainable entrepreneurship, triple-win organisation, change-oriented business, new way of doing business, etc., to rally their cause. Of course there are real differences, but the likenesses are nevertheless larger. In addition, the niche does not seem interested in solving this confusion, retorting that it would limit their freedom of operations. As noted above, this independent attitude is probably a result of fighting against established rules, institutions and organisations for their right to exist, and is thus a perfectly understandable characteristic of the niche actors. However, now that the niche is slowly arriving at a consolidation point, this attitude is starting to become problematic, at least if further growth of the niche in envisioned. A confusing plethora of new types of organisations, business models and consequently vocabulary is not conducive to creating a greater confidence in the niche and thus to growth. Especially the business regime is used to clearly defined tasks (in contracts) and measures of performance.

Conflicting value 3: The social entrepreneurship niche actors refuse to standardise their vocabulary. (between social entrepreneurship niche and business regime)

Traditional civil society organisations are driven by a mission that benefits society as a whole (vs. private interests) and are funded by gifts, subsidies and donations. Their ability to attract these funds depends on the credibility with which they are perceived to pursue their mission. Their non-profit character has enabled them to gain society's trust and therefore credibility and donations. Because they are not subject to shareholders, they can pursue their mission indefinitely, albeit with sometimes heavily fluctuating income and thus operational reach. Finally, however, some social entrepreneurs have started to undertake similar social mission-oriented action while building their obtained trust on other organisational characteristics than on being non-profit. It is not yet precisely clear what the basis of this trust is for social entrepreneurs, but it will undoubtedly have to do with the organisations' mission statements and the sincerity of the social entrepreneurs themselves. This entrepreneurial activity inherently undermines the credibility of traditional civil society organisations, since why should people donate when you can solve the problem while making money at the same time? Add to that the ever more purveying faith that society has put in the usefulness of competition in achieving efficient organisations, and it becomes clear that civil society organisations have a 
right to feel endangered by social entrepreneurs. Interestingly, social entrepreneurs typically associate more with the business than with the civil society regime, while it is thus more a competitor of the latter than of the first. Certainly not all social entrepreneurs make a profit, or aim to make one, and many can be said to appear to be more like civil society organisations than business ones, but the fact that trust and legitimacy to act is based on a different presumption makes these two unlikely to interact much in the foreseeable future. This effect was indeed found in the survey respondents' answer to who their most important partners were, only 5\% of which belong to civil society.

Conflicting value 4: Society's trust in civil society organisations is based on their non-profit character. (between social entrepreneurship niche and civil society regime)

One of the advantages of social entrepreneurs being double bottom-lined is that they share one bottom-line with each of the two regimes they challenge, giving them a shared value with each. Their dedication to maintain financial sustainability and to not depend solely on gifts and subsidies but instead (partly) on earned income, enable them to communicate with business in terms of mutual understanding. This understanding, however, is limited, since social entrepreneurs do not share the value of profit maximisation with business, and are also more comfortable with gifts and subsidies than business is.

With the civil society regime, social entrepreneurs share their social mission. At first glance, most social entrepreneurs will even appear to be civil society organisations because it is the social mission that drives them. Different beliefs concerning financial sustainability, however, can lead the niche and regime actors to recoil from each other (as explained in conflicting value four), especially civil society from social entrepreneurs, driving social entrepreneurs to interact more with another regime, namely government. This other regime is not discussed in this article because it is not a competitor to the niche, but it is interesting here because it shares the social motivation with both civil society and social entrepreneurs and also is sufficiently detached from monetary considerations to be able to appreciate the latter's double bottom-line approach. In other words, while social entrepreneurs share the social motivation with civil society, the conflicting value described above will nevertheless strongly complicate collaboration between the niche and this regime.

Shared value 1: Social entrepreneurs are comfortable with competition for financial resources. (between social entrepreneurship niche and business regime)

Shared value 2: Social entrepreneurs are recognised as legitimate social problem solvers. (between social entrepreneurship niche and civil society regime)

SE has a strong relation to innovation. Ashoka (one of the internationally leading organisations supporting social entrepreneurs, though not active in the Netherlands), for example calls their fellows 'innovators for the public' and Alvord et al. (2004) describe the whole phenomenon as 'creat(ing) innovative solutions to immediate social problems (...)'. Though this article discusses the rise of SE as an innovation 
in itself-i.e. on a macro scale-social entrepreneurs are thus also innovative as individuals. This innovative stance results in ambiguous reactions, on the one hand sometimes evoking resistance to change, while on the other hand this change is highly coveted. The high costs incurred on companies and governments by social problems, such as, for example by health issues, unmotivated employees or unemployment, lead many of these organisations to be of the latter type and to search for solutions to their social problems. Inevitably, those solutions will require innovation. Given the often complicated character of social problems and the number of interacting issues and actors that play in role in them (e.g. Mulgan et al. 2007), those best able to perceive and implement the necessary innovation will be those organisations with views of both sides (i.e. business and civil society sides) of the problems at hand. Thus, the combination of the social entrepreneurs' innovativeness and their multi-valued approach to doing business allows them to be perceived as valuable business partners.

Shared value 3: Multi-valued innovation is best suited for solving complex social problems and is best practiced by social entrepreneurs. (between social entrepreneurship niche and both business and civil society regimes)

\section{Analysis and Conclusions}

The SNM analysis of SE, as carried out in the methodology and the results sections, has disclosed much information about the niche and its relation to the incumbent regimes. This section concludes the results of this undertaking. Subsequently, a discussion of these results concludes the article.

\section{Growth Perspectives of Social Entrepreneurship}

Interest in SE and activities of social entrepreneurs is growing, in the Netherlands as elsewhere. While the niche is still far from mature, the initial days of monological and tireless individuals as described by, e.g. Bornstein (2004) seem either over or nearly so, and the niche is seen to put increasing effort into relationships with actors from the incumbent regimes in an effort to gain a larger market share. Whether this will succeed depends both on the strength of the niche itself, and on its relationship to the regimes whose rules and routines it challenges, namely the business and civil society regimes.

A niche characteristic that, looking at this sample, appears to be well developed, especially considering the young age and low geographical density of the niche, is its social network. There are numerous networking events and joint projects within the niche. However, there are exceptions to this observation namely that (a) the regulatory hand of the government is absent from these networks; (b) there is a perceived shortage of involved investors and (c) social entrepreneurs have a hard time meeting potential clients and partners. The latter two shortcomings are reflected upon in the learning mechanisms paragraph below, but the first one is puzzling. Perhaps social entrepreneurs have not managed to convince policy makers 


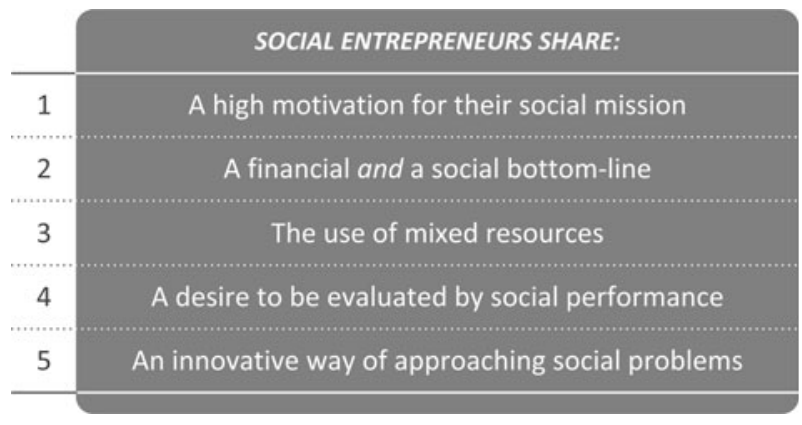

Fig. 6 Five shared characteristics of social entrepreneurs

that they are indeed a special breed. Even while there are considerable differences amongst social entrepreneurs and many even use a different name to distinguish themselves with, there also appear to be five universally shared characteristics, as found in the results, namely that social entrepreneurs (a) are highly motivated by their social mission, (b) attach an equally high value to their financial and a social bottom-lines and a lower value to their environmental one, (c) use mixed financial resources, (d) would like their organisation to be judged upon by its social performance and (e) use innovative ways to create social value by combining methods from different sectors (see Fig. 6). These characteristics reveal the group's expectations for SE. ${ }^{11}$ The benefit of shared characteristics, however, are partly offset by the niche actors' reluctance to acknowledge them. The lack of a dedicated legal entity for social entrepreneurs, such as, for example the CIC in the United Kingdom (CIC 2007), further complicates the standardisation of the vocabulary that is used by the niche actors. Concluding this paragraph, there thus appear to be extensive similarities between niche actors, but they focus instead on how they are different from each other. This attitude leads, a.o., to the above-mentioned difficulties in finding clients, partners and in convincing investors.

While a good degree of the interviewed niche actors are devoted to knowledge diffusion and experience sharing, hence learning mechanisms, there is still a perceived shortage of these sources amongst social entrepreneurs. This is possibly a result of the lack of a widely accepted standard body of learning (i.e. learning on the 'global level', see, e.g. Geels and Raven 2006, p. 377) on SE, to which individual entrepreneurs could contribute their experience, and from which new ones could extract valuable lessons.

For future growth, social entrepreneurs will continue on the path already set out upon, interacting more and more with actors from competing regimes. The two regimes used in this article to contrast with SE, the business and civil society regimes, are to a different degree receptive to the niche's expansion. Note that these descriptions will hold for the regimes as a whole, but that individual regime actors may react differently.

\footnotetext{
${ }^{11}$ It unveils these expectations, or at least partly so. See the discussion section for more detail.
} 
The business regime tends to understand the added value that social entrepreneurs can bring, namely multi-valued innovation that is likely to also take into account costs that current types of innovation and organisation have great difficulty in finding. They also value the social entrepreneurs' competitive stance towards performance on both social and financial issues. However, social performance is generally not adequately measured or communicated throughout the company and the support for expenses in this field may therefore be fickle. Strengthening the niche (e.g. harmonising social performance measurement) could combat this obstacle. Nevertheless, for the time being, this makes social entrepreneurs more likely to function as innovation consultants to a company that itself experiences the costs of, for example unmotivated employees or community resistance, than to institutional investors who are themselves evaluated only by financial performance by someone further down the line.

The civil society regime should be more troubled by the rise of the social entrepreneur, because it has the power to jeopardise the regime's legitimacy to attract funds. When people observe that social entrepreneurs can contribute to solving social issues while being (more) financially independent, they will be less inclined to support the traditional civil society organisations. Nevertheless, many individual organisations and people in this regime appreciate the positive influence that social entrepreneurs have on levels of social innovation. Some organisations also support social entrepreneurs or themselves translate in the direction of a more entrepreneurial attitude towards solving social problems. These relationships are valuable, but the underlying conflict of legitimacy makes future cooperation between the niche and this regime questionable.

$\mathrm{SE}$ is in a transitional phase, from a rough cowboy market to a more established market niche. This article has shown that several difficulties that social entrepreneurs currently face result from an attitude that is still more in line with this formerly justified cowboy behaviour than with the new role they are expected to take on.

Conclusion I: The social entrepreneur's continued cowboy attitude results in numerous obstacles to growth of the niche.

Both theoretically and practically, social entrepreneurs stand on the crossroads of business and civil society. That gives them their unique position to understand both and to come up with innovative solutions to complex problems, but it also means that they are expected to be sensitive to the people that populate the regimes on either side of their position. They should forget about the romanticism of pioneering cowboys, and focus on how to be the bridging diplomats. That requires a number of reflections, one side of which enables them to communicate better with business, the other side of which enables them to co-exist better with civil society.

For relations with the business regime, social entrepreneurs should:

(a) change focus from the characteristics that divide them to what unites them;

(b) find a way to market these characteristics and

(c) to search for a way that allows the evaluation of social performance to be comparable between organisations. 
This last point is something not covered in this article but on which a lot of work has already been done, for example the social return on investment (SROI) theory (REDF 2000), and on which a lot more work is likely to be necessary. However, this article would like to note that the development of such an indicator will inherently be a never-ending process and that it could be more important at this time to use a standardised and evolving measure that is far from perfect than to use no measure at all.

For relations with the civil society regime, social entrepreneurs should:

(a) be sensitive to possible legitimacy issues that civil society organisations may experience and

(b) reflect on the kind of issues that allow for a social entrepreneurial approach and issues that do not-in effect creating an analytical line that could keep the niche and regime out of conflict.

In addition, the civil society regime actors are advised to rethink their position (for example why not strive for a diversification of resources and a more entrepreneurial stance towards solving the social problem covered by their mission?). To an extent, this is already taking place.

Besides these measures dedicated to facilitate the increasingly diplomatic role of social entrepreneurs in society, the following suggestions are aimed at strengthening the niche an sich:

Social entrepreneurs should strengthen their niche by:

(a) building a 'global level' of knowledge for SE that is based on shared characteristics and

(b) actively seeking the involvement of the national government, especially for the establishment of a dedicated and suitable legal entity (i.e. a strong method of identification, standardisation and marketing) and the harmonisation of innovation subsidy rules with the practice of SE.

Such a global level of knowledge will facilitate new start-ups and, by the (limited) standardisation of used terminology, speed up the accumulation and diffusion of methods for increased social innovation and appropriate business models.

These recommendations for growth of the niche, aimed at stimulating social entrepreneurs to become diplomats instead of cowboys, complement the first conclusion. In many ways, these recommendations urge social entrepreneurs to institutionalise and thus lose a part of their unique current position to innovate from without any of the established institutions. This loss is what Sud et al. (2008) deplore and what leads them to lower their expectations of SE. This article has tried to show, amongst others, that such loss is unpreventable-even desirable because diffusion will otherwise not occur-and need not be detrimental to the innovative capacities of social entrepreneurs. What is required is that social entrepreneurs face the isomorphic pressures by agreeing internally on a set of core values that they must not give up on. The final conclusion, then, is:

Conclusion II: Social entrepreneurship can grow without compromising its core values by acknowledging the existence of these core values and their 
incompatibility with the respective regimes, and then focusing instead on the values it shares with these regimes.

As previous sections show, the acknowledgement of the social entrepreneur's core values is not yet undertaken on the global niche level. If these values, however, are not clear, it is likely that the interaction with business and civil society regimes, whose conflicting values will challenge the social entrepreneur's values be they recognised or not, will result in compromises of core niche values. The interaction with business and civil society regimes, nevertheless, is of high importance for the growth perspectives of the SE niche, and social entrepreneurs should therefore not cease to seek this interaction. In doing so, they should be aware of possible conflicts. They are likely to achieve the best results and the lowest degree of conflicts when focusing on those areas in which their niche and the respective regime understand or complement each other. This stipulates the need for social entrepreneurs to understand the regimes with which they compete and cooperate.

\section{Discussion}

In this particular research, we decided to take into account only those businesses that define themselves as social entrepreneurs-mostly small scale and relatively young-instead of taking a wider sample including social enterprises such as hospitals, housing corporations or organisations that support these. The latter has a longer history, includes larger organisations and has given rise to a greater body of literature, a.o. De Waal et al. (1994). The most important reason for not grouping these two related categories into one is that social entrepreneurs consider themselves to be different from social enterprise, namely more entrepreneurial and innovative. It would be an interesting topic for further research, especially in The Netherlands with its long history of public service providing business, to compare these two related types of organisations. For the current article, this results in a clear, albeit intended, limitation of the data set.

The five shared characteristics of social entrepreneurs that this article found are used to reflect on the need for standardisation of the niche's terminology and the subsequent reaching out of the niche to actors from without. It, however, is not the intention of this article to impose from above that these are indeed the actual and only characteristics. These five characteristics are perhaps suitable as a starting point for discussion and a bottom-up establishment of shared characteristics and values within the niche.

The findings brought forth by this exercise prompt further research into the following issues: (a) the possibilities for a country-wide platform uniting all actors engaged in SE, and its tasks as envisioned by these actors; (b) the requirements for a comparative measure of social performance, especially as seen by investors; (c) the reasons for the apparent inability of government to react to the development of SE; and, finally, (d) whether there is a definable line between social problems that can be tackled in a social entrepreneurial way and ones that cannot. 
Open Access This article is distributed under the terms of the Creative Commons Attribution Noncommercial License which permits any noncommercial use, distribution, and reproduction in any medium, provided the original author(s) and source are credited.

\section{References}

Abernathy, W. J. (1978). The productivity dilemma: Roadblock to innovation in the automobile industry. Baltimore, MD: Johns Hopkins University Press.

Alvord, S. H., Brown, L. D., \& Letts, C. W. (2004). Social entrepreneurship and societal transformation. Journal of Applied Behavioral Science, 40(3), 260-282.

Bornstein, D. (2004). How to change the world: Social entrepreneurs and the power of new ideas. Cambridge, MA: Oxford University Press.

Borzaga, C., \& Defourny, J. (Eds.). (2001). The emergence of social enterprise. NY: Routledge.

Boschee, J. (2001). The social enterprise sourcebook. Minneapolis, MN: Northland Institute.

Carnegie, A., \& Van Dyke, J. C. (1920). Autobiography of Andrew Carnegie. Cambridge, MA: Houghton Mifflin.

Centraal Bureau voor Statistiek (Central Statistics Bureau of the Netherlands). (2008). Statline public database. Available at http://statline.cbs.nl.

Cho, A. H. (2006). Politics, values and social entrepreneurship: A critical appraisal, chapter 4. In J. Mair, J. Robinson, \& K. Hockerts (Eds.), Social entrepreneurship. NY: Palgrave Macmillan.

Clark, C. H., \& Ucak, S. (2006). RISE for-profit social entrepreneur report: Balancing markets and values. NY: Columbia Business School.

Community Interest Companies (CICs). (2007). The regulator of briefing pack. Available at http://www.cicregulator.gov.uk.

De Waal, S. P. M., Schuyt, T. N. M., \& Verveen, P. A. (1994). Handboek maatschappelijk ondernemerschap. Houten: Bohn Stafleu Van Loghum.

Dees, J. G. (1998). The meaning of "social entrepreneurship" (Stanford University, Draft report for the Kauffman Center for Entrepreneurial Leadership).

Dees, J. G., Anderson, B. B., \& Wei-Skillern, J. (2004). Scaling social impact: Strategies for spreading social innovations. Stanford Social Innovation Review, 1(4), Spring.

Dees, J. G., Economy, P., \& Emerson, J. (2002). Strategic tools for social entrepreneurs: Enhancing the performance of your enterprising nonprofit. Somerset, NJ: Wiley.

Elzen, B., Hoogma, R., \& Schot, J. (1996). Mobiliteit met toekomst; naar een vraaggericht technologiebeleid. Report to the Ministry of Traffic and Transport. Rotterdam, Netherlands: Adviesdienst Verkeer en Vervoer (Rijkswaterstaat).

Friedman, M. (1970). The social responsibility of business is to increase its profits. The New York Times Magazine, 13 September.

Geels, F. (2004). From sectoral systems of innovation to socio-technical systems: Insights about dynamics and change from sociology and institutional theory. Research Policy, 33, 897-920.

Geels, F., \& Raven, R. (2006). Non-linearity and expectations in niche-development trajectories: Ups and downs in Dutch biogas development (1973-2003). Technology Analysis \& Strategic Management, 18(3/4), 375-392.

Hofstede, G. (1980). Culture's consequences: International differences in work-related values. Newbury Park, CA: Sage Publications.

Jones, M. B. (2007). The multiple sources of mission drift. Nonprofit and Voluntary Sector Quarterly, 36, 299-307.

Kerlin, J. A. (2006). Social enterprise in the United States and Europe: Understanding and learning from the differences. Voluntas, 17, 247-263.

Kievit, H. (2011). Social venturing entrepreneurship: A topography. Doctoral dissertation, Nyenrode Business University, Breukelen, Netherlands (forthcoming).

Kievit, H., van Dijk, G., \& Spruyt, B. J. (2008). De stille revolutie van social venturing entrepreneurs. Holland Management Review, 120, 20-25.

Leadbeater, C. (1997). The rise of the social entrepreneur. London: Demos.

Maase, S., \& Dorst, K. (2007). Exploring the development process of grassroots social entrepreneurship. In Proceedings of the third international social entrepreneurship research conference (Kopenhagen, Denmark: ISERC), 18-19 June 2007 (no page numbers in original). 
Mair, J., Robinson, J., \& Hockerts, K. (Eds.). (2006). Social entrepreneurship. NY: Palgrave Macmillan.

Mulgan, G., Tucker, S., Ali, R., \& Sanders, B. (2007). Social innovation: What it is, why it matters and how it can be accelerated. Oxford, England: Oxford Saïd Business School.

Murphy, P. J., \& Coombes, S. M. (2008). A model of social entrepreneurial discovery. Journal of Business Ethics, 87(3), 325-336.

Nicholls, A. (Ed.). (2006). Social entrepreneurship: New models of sustainable social change. NY: Oxford University Press.

Peredo, A. M., \& McLean, M. (2006). Social entrepreneurship: A critical review of the concept. Journal of World Business, 41, 56-65.

REDF (formerly Roberts Enterprise Development Fund). (2000). The social return on investment collection (various white papers published online, available at http://www.redf.org).

Reich, R. B. (2007). Supercapitalism: The transformation of business, democracy, and everyday life. NY: Knopf Inc.

Renooy, P. H. (2001). The Netherlands: Neighbourhood development enterprises, chapter 14. In C. Borzaga \& J. Defourny (Eds.), The emergence of social enterprise. NY: Routledge.

Schot, J., \& Geels, F. (2008). Strategic niche management and sustainable innovation journeys: Theory, findings, research agenda, and policy. Technology Analysis \& Strategic Management, 20(5), 537-554.

Schot, J., Slob, A., \& Hoogma, R. (1996). De invoering van duurzame technologie: strategisch niche management als beleidsinstrument. Delft, The Netherlands: Programma DTO, Delft University of Technology.

Smith, A. (2007). Translating sustainabilities between green niches and socio-technical regimes. Technology Analysis \& Strategic Management, 9(4), 427-450.

Sud, M., VanSandt, C. V., \& Baugous, A. M. (2008). Social entrepreneurship: the role of institutions. Journal of Business Ethics, 85, 201-216.

Tan, W. L., Williams, J., \& Tan, T. M. (2005). Defining the 'social' in 'social entrepreneurship': Altruism and entrepreneurship. International Entrepreneurship and Management Journal, 1, 353-365.

Weisbrod, B. A. (2004). The pitfalls of profits. Stanford Social Innovation Review, 2(3), 40-47. 